\title{
ASSOCIATION OF THE MMP7 -181A>G PROMOTER POLYMORPHISM WITH EARLY ONSET OF CHRONIC OBSTRUCTIVE PULMONARY DISEASE
}

\author{
Tacheva $\mathrm{T}^{1, *}$, Dimov $\mathrm{D}^{2}$, Anastasov A ${ }^{1}$, Zhelyazkova $\mathrm{Y}^{2}$,
}

Kurzawski $\mathrm{M}^{3}$, Gulubova $\mathrm{M}^{4}$, Drozdzik $\mathrm{M}^{3}$, Vlaykova $\mathrm{T}^{1}$

\begin{abstract}
*Corresponding Author: Assistant Professor Tanya Tacheva, Department of Chemistry and Biochemistry, Medical Faculty, Trakia University, 11 Armeiska Str., Stara Zagora, Bulgaria. Tel: +359878334176. E-mail: tanya.ta4eva@abv.bg
\end{abstract}

\begin{abstract}
Chronic obstructive pulmonary disease (COPD) is characterized by decreased air flow and is associated with abnormal chronic inflammation in the airways and extensive tissue remodeling. Matrix metalloproteinase-7 (MMP7) is produced primarily by the epithelium of many organs, including the lungs. A functional MMP7-181A>G (rs11568818) promoter polymorphism influences the binding of nuclear regulatory proteins modulating the transcription of the gene. In this study, we genotyped 191 patients with COPD for MMP7 -181A>G single nucleotide polymorphism (SNP) and 215 control subjects using the polymerase chain reaction-restriction fragment length polymorphism (PCR-RFLP) method and explored the role of that polymorphism as a risk factor for COPD. There were no differences in the genotype and allele distribution of the MMP7 $-181 \mathrm{~A}>\mathrm{G}$ SNP between the COPD patients and control groups ( $p=0.341$ and $p=0.214)$. However, the carries of the $\mathrm{G}$ allele (AG and GG genotypes), appeared to develop COPD significantly earlier than those with the AA genotype (61.01 \pm 10.11 vs. $64.87 \pm 9.00$ years, $p=0.032$ ). When the genotype distribution was studied only in the groups of patients $(n=76)$ and controls $(n=106)$ younger than 60 years, we found significantly higher frequency of the carriers of the $\mathrm{G}$ allele in COPD patients than in the controls, determining about a 3-fold higher risk for COPD [odds ratio (OR) -3.33, 1.36-8.14, $p=0.008$ for $G G$, and

\footnotetext{
${ }^{1}$ Department of Chemistry and Biochemistry, Medical Faculty, Trakia University, Stara Zagora, Bulgaria Stara Zagora, Bulgaria

${ }^{3}$ Department of Experimental and Clinical Pharmacology, Pomeranian Medical University, Szczecin, Poland

${ }^{4}$ Department of General and Clinical Pathology, Medical Faculty, Trakia University, Stara Zagora, Bulgaria
}

${ }^{2}$ Department of Internal Medicine, Medical Faculty, Trakia University,
\end{abstract}

$\mathrm{OR}=2.91,1.38-6.13, p=0.005$ for $\mathrm{AG}+\mathrm{GG}]$. Based on our results, the MMP7 $-181 \mathrm{~A}>\mathrm{G}$ promoter variant may influence early development of COPD. This effect could be attributed to the increased production of the enzyme resulting in enhanced airway wall protein degradation and injury.

Keywords: Age; Chronic obstructive pulmonary disease (COPD); Matrix metalloproteinase-7 (MMP7); Polymorphisms; Risk.

\section{INTRODUCTION}

Chronic obstructive pulmonary disease (COPD) is a preventable and treatable disease with some significant extrapulmonary effects that may contribute to its severity in individual patients. Its pulmonary component is char-acterized by airflow limitation that is not fully reversible. The airflow limitation is associated with an abnormal inflammatory response of the lung to noxious particles or gases [1].

Smoking is one of the main risk factors for COPD, but since not all smokers develop COPD, as well as the fact that the disease often develops in middle age, it is suggested that other factors may play a role in the pathogenesis such as genetic factors [2]. Inhalation of cigarette smoke, organic and/or inorganic dust, chemical agents and particle matters increase the risk of developing COPD. The presence of these irritants, may lead to chronic inflammation and structural changes in the lung due to repeated injury and repair [3]. Pathological changes characteristic for COPD are found in the proximal airways, peripheral airways, lung parenchyma and pulmonary vasculature [4].

One of the main roles of the epithelial cells is to provide a barrier against pathogens and to release antimicrobial products. By producing chemoattractants and adhesion molecules, epithelial cells contribute to the migration of the inflammatory cells to injury sites $[5,6]$. Epithelial 
damage is an important characteristic of several pulmonary diseases including COPD. Numerous enzymes, proteins and peptides are involved in the process of tissue repair and remodeling [7].

The matrix metalloproteinases (MMPs) family is composed of more than 25 zinc-dependent proteases that cleave the extracellular matrix and cell-surface proteins to regulate wound healing, physiological angiogenesis and immune response [8]. Matrix metalloproteinases can activate and increase the bioavailability of a variety of non matrix proteins, including cytokines, chemokines, recep-tors and antimicrobial peptides [5,9]. Matrilysin 1 (MMP-7), unlike many MMPs, is expressed by non injured, non inflamed mucosal epithelia in most adult human tissues (7). Besides extracellular matrix (ECM) components, MMP-7 processes cell surface molecules such as pro-defensin, Fas-ligand, pro-tumor necrosis factor (TNF), and E-cadherin [10,11].

The production of the enzyme is highly up-regulated by injury or exposure to bacteria, stimulating cell migration and coordinating the inflammatory response [12-14]. Thus, MMP-7 participates in the processes of defense, repair and inflammation.

In the promoter of the gene of MMP-7 an A>G transition has been identified as a functional polymorphism (MMP7 -181A>G; rs11568818). The polymorphism has been shown to modulate transcriptional activity by influencing the binding of nuclear regulatory proteins. The $G$ allele has greater basal transcriptional activity than the $\mathrm{A}$ allele in vitro experiment in the human monocyte/ macrophage cell line U937 [15]. The nuclear proteins bind with higher affinity to the $\mathrm{G}$ allele than to the A allele, resulting in significant increase in promoter activity $[16,17]$.

So far, there are only very limited studies concerning the role of MMP-7 and its genetic variants in lung diseases such as lung cancer [18], pneumoconiosis [19], bron-chiolitis obliterans syndrome (BOS) in patients after lung transplantation [20], and idiopathic pulmonary fibrosis (IPF) [21]. Concerning COPD, there was only one report showing increased serum level of MMP-7 in patients exposed to biomass and tobacco smoke compared with non smoking healthy controls, and the levels were negatively correlated with spirometric index of lung function (FEV1 \%pr.) [22]. However, there has only been one study exploring the functional variants of MMP-7 in the development of COPD [23].

In this respect we aimed to evaluate the possible role of the MMP7-181A $>\mathrm{G}$ promoter polymorphism as predisposing factor for COPD in a population from the region of Stara Zagora, Bulgaria.

\section{MATERIAL AND METHODS}

Patients and Controls. We have genotyped $191 \mathrm{pa}-$ tients with COPD and 215 healthy volunteers or individuals unaffected by lung or cancer diseases. The inclusion criteria for COPD were as follows: age higher than 40 years; forced expiratory volume in one second (FEV1) of $<80.0 \%$; forced expiratory volume in one second (FEV1)/ forced vital capacity (FVC) ratio of $\leq 70.0 \%$; FEV1 reversibility after inhalation of $400 \mu \mathrm{g}$ Salbutamol of $<12.0 \%$.

In both groups, the age of inclusion in the study and smoking status were noted; in the patients' group: age of diagnosis, the spirometric indexes, duration and the stages of the disease (GOLD stages) were also reported. The available demographic and clinical data are presented in Table 1. Informed consent was obtained from patients and controls before the beginning of the study.

DNA Isolation and Genotyping. Genomic DNA was isolated from $0.2 \mathrm{~mL}$ of whole blood using a commercial kit for isolation of genomic DNA from blood (GenElute ${ }^{\mathrm{TM}}$ Mammalian Genomic DNA Miniprep Kit, Sigma-Aldrich, St. Louis, MO, USA).

The genotyping for the MMP7-181A > G (rs11568818) was performed by the polymerase chain reaction-restriction fragment length polymorphism (PCR-RFLP)-based method. The final volume of each reaction was $15 \mu \mathrm{L}$, containing 0.5 U Dream Taq Polymerase (Fermentas, Waltham, MA, USA), $1.5 \mu \mathrm{L} 10 \times$ PCR buffer (with 1.5 $\mathrm{mM}$ MgCl2), $0.6 \mu \mathrm{L}$ dNTPs (Sigma-Aldrich) in a final concentration of $200 \mu \mathrm{M}$ for each of the four dNTPs, $0.3 \mu \mathrm{L}$ of each primer in concentration of $20 \mathrm{pmol} / \mu \mathrm{L}$ (MMP7F: 5'-TGG TAC CAT AAT GTC CTG AAT G-3'; MMP7R: 5'-TCG TTA TTG GCA GGAAGC ACA CAA TGAATT3') and distilled water to the end volume.

The temperature profile of the PCR reactions included primary denaturing of the template DNA for $3 \mathrm{~min}$. at $94^{\circ} \mathrm{C}$, followed by 30 cycles of denaturation for $30 \mathrm{sec}-$ onds at $94^{\circ} \mathrm{C}$, annealing for 30 seconds at $53.6^{\circ} \mathrm{C}$ and poly-merization for 30 seconds at $72^{\circ} \mathrm{C}$. The PCR reaction was terminated by a final extension for $5 \mathrm{~min}$. at $72^{\circ} \mathrm{C}$.

The restriction reaction was performed with $5 \mathrm{U}$ EcoRI in final volume of $5 \mu \mathrm{L}$ for 16 hours at $37^{\circ} \mathrm{C}$. The obtained restriction products were analyzed by $4.0 \%$ agarose gel stained with ethidium bromide. The results were documented by the Gel documentation system (Syngene; Synoptics Ltd., Cambridge, Cambridgeshire, UK).

Statistical Analyses. Statistical analyses were performed using the Statistical Package for the Social Sciences (SPSS), version 16.0 for Windows (SPSS Inc., Chicago, IL, USA). Continuous variables were analyzed for 
Table 1. Demographic and clinical data of patients with chronic obstructive pulmonary disease and controls.

\begin{tabular}{|c|c|c|c|}
\hline Characteristics & Patients with COPD (\%) & Controls (\%) & $p$ Value \\
\hline $\begin{array}{l}\text { Number } \\
\text { males } \\
\text { females }\end{array}$ & $\begin{array}{r}191 \\
146(76.4) \\
45(23.6)\end{array}$ & $\begin{array}{l}215 \\
109(50.7) \\
106(49.3)\end{array}$ & $<0.001^{\mathrm{a}}$ \\
\hline $\begin{array}{l}\text { Age (years) at inclusion in the study } \\
\text { median (range) }\end{array}$ & $67(36-88)$ & $59(18-80)$ & $<0.001^{\text {b }}$ \\
\hline $\begin{array}{l}\text { Age (years) at diagnosis of the disease } \\
\text { median (range) }\end{array}$ & $64(30-86)$ & - & \\
\hline $\begin{array}{l}\text { Smoking status } \\
\text { non-smokers } \\
\text { ex-smokers } \\
\text { current smokers }\end{array}$ & $\begin{array}{l}n=186 \\
54(29.0) \\
89(48.0) \\
43(23.0)\end{array}$ & $\begin{array}{l}n=164 \\
97(59.0) \\
25(15.0) \\
42(26.0)\end{array}$ & $<0.001^{\mathrm{a}}$ \\
\hline FEV1 \%pr (mean \pm SD) (range) & $50.60 \pm 14.10(15-79)$ & $93.40 \pm 11.90(82-114)$ & $<0.001^{\mathrm{b}}$ \\
\hline FEV1/FVC $\%$ (mean \pm SD (range & $61.1 \pm 8.6(27.1-70.0)$ & $80.4 \pm 7.2(76.3-93.0)$ & $<0.001^{\mathrm{b}}$ \\
\hline $\begin{array}{l}\text { COPD staging (GOLD 2009) } \\
\text { stage II (moderate) } \\
\text { stage III (severe) } \\
\text { stage IV (very severe) }\end{array}$ & $\begin{array}{c}102(55.0 \%) \\
73(39.0) \\
11(67.0)\end{array}$ & $\begin{array}{l}- \\
- \\
-\end{array}$ & \\
\hline
\end{tabular}

COPD: chronic obstructive pulmonary disease; SD: standard deviation.

${ }^{\text {a }}$ Determined by the $\chi^{2}$ test.

${ }^{\mathrm{b}}$ Determined by the Mann-Whitney U test.

normality of the distribution using the Kolmogorov-Smirnov test (One-Sample Kolmogorov-Smirnov D-Test in SPSS, version 16; SPSS Inc.). When the level of signif-icance in this test was lower than 0.05 ( $p<0.05$ ), the hypothesis for normal distribution was rejected. The continuous variables with normal distribution were com-pared between two or more independent groups by the Student $t$-test or one-way analysis of variance (ANOVA) test with least significant difference (LSD) post hoc ana-lysis, while those with an abnormal distribution were analyzed with the Mann-Whitney U or Kruskal-Wallis tests. The frequencies of distribution in the contingency tables were analyzed using $\chi^{2}$ test, or Fisher's exact test, when needed. The odds ratio (OR) and $95 \%$ confidence interval $(95 \% \mathrm{CI})$ were calculated by binary logistic regression with age and sex as covariates. The Hardy-Weinberg equilibrium (HWE) was calculated by an inter-active calculation tool for $\chi^{2}$ tests of goodness of fit and independence [24]. Factors with a $p$ value of $<0.05$ were considered to be statistically significant.

\section{RESULTS}

The PCR product amplified with the primers for MMP7 -181A > G was 150 bp in length. The EcoRI digestion resulted in $150 \mathrm{bp}$ for the AA genotype, 150, 120 and $30 \mathrm{bp}$ for the AG genotype, and 120 and $30 \mathrm{bp}$ for the GG genotype (Figure 1).

The genotype distribution in both controls and patients did not deviate from $\operatorname{HWE}(p=0.998$ and $p=0.999)$. After statistical processing of the data, we found no differences in the genotype and allele distribution of the MMP7 -181A > G polymorphism between COPD patients and controls ( $p=0.341$ and $p=0.214$ ) (Table 2$)$. In the group of patients, there was no association between the genotype

Table 2. Genotype and allele frequencies of the $M M P 7-181 \mathrm{~A}>\mathrm{G}$ gene polymorphism in patients with chronic obstructive pulmonary disease and controls.

\begin{tabular}{|c|c|c|c|c|c|c|}
\hline \multirow[t]{2}{*}{$M M P 7-181 \mathrm{~A}>\mathrm{G}$} & \multicolumn{2}{|c|}{ Patients } & \multicolumn{2}{|c|}{ Controls } & \multirow[t]{2}{*}{ OR (95\% CI) } & \multirow[t]{2}{*}{$p$ Value } \\
\hline & $n=191$ & Frequency & $n=215$ & Frequency & & \\
\hline \multicolumn{7}{|c|}{ Genotype frequency } \\
\hline AA & 43 & 0.225 & 54 & 0.251 & 1.0 (referent) & \\
\hline AG & 99 & 0.518 & 119 & 0.554 & $1.465(0.826-2.598)$ & 0.243 \\
\hline GG & 49 & 0.257 & 42 & 0.195 & $1.045(0.647-1.687)$ & 0.903 \\
\hline AG+GG & 148 & 0.775 & 161 & 0.749 & 1.154 (0.731-1.823) & 0.562 \\
\hline \multicolumn{7}{|l|}{ Allele frequency } \\
\hline$-181 \mathrm{~A}$ & 185 & 0.484 & 227 & 0.528 & 1.0 (referent) & \\
\hline$-181 \mathrm{G}$ & 197 & 0.516 & 203 & 0.472 & $1.191(0.904-1.569)$ & 0.232 \\
\hline
\end{tabular}

OR: odds ratio; $95 \% \mathrm{CI}: 95 \%$ confidence interval. 


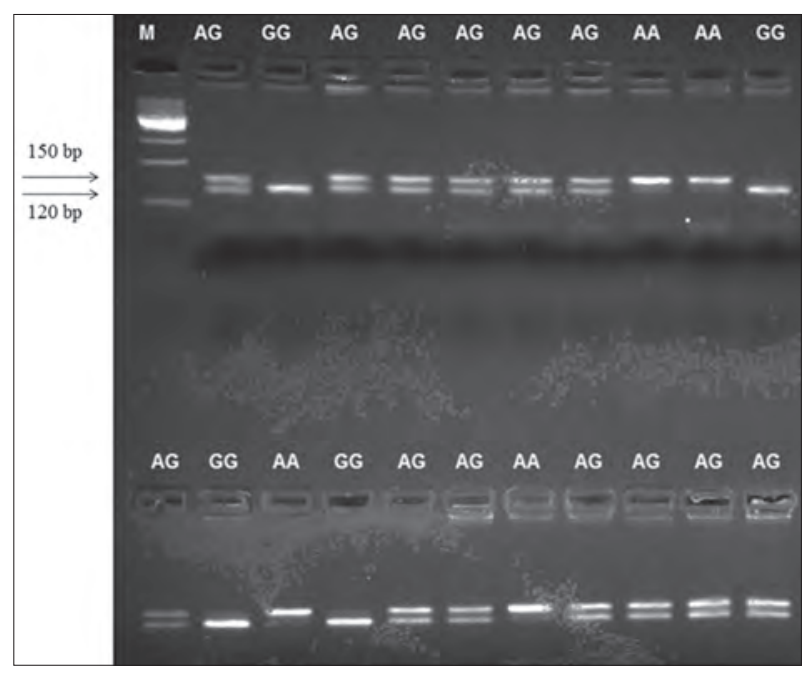

Figure 1. Agarose gel for visualization of the PCR-RFLP products and $M M P 7-181 \mathrm{~A}>\mathrm{G}$ genotyping.

and gender ( $p=0.358)$, smoking habit ( $p=0.587)$, stage of the disease ( $p=0.924$ ) or spirometric indexes for lung function (for FEV1: $p=0.598$ and for FEV1/FVC: $p=0.3$, Kruskal-Wallis test). Association of the MMP-7 G allele with severity of COPD was also not found ( $p=0.876)$.

However, the carriers of the G allele (AG and GG genotypes) appeared to develop COPD significantly early compared to those with the AA genotype (61.01 \pm 10.11 vs. $64.87 \pm 9.00$ years, $p=0.032$, Student $t$-test). When the genotype distribution was studied only in the patients $(n=76)$ and controls $(n=106)$ younger than 60 years, significant difference was found. The frequency of the carriers of the $G$ allele (AG and GG genotypes), was higher in COPD patients than in controls, showing a 3-fold higher risk for the development of COPD before the age of 60 years (Table 3).

\section{DISCUSSION}

A common feature of COPD is the chronic in inflammation in the airways and the development of extensive tissue remodeling during the course of the disease process [25]. The matrix metalloproteinases are a family of zinccontaining enzymes with proteolytic activity against a wide range of extracellular proteins [10]. Under normal physiological conditions, the activities of MMPs are precisely regulated at the level of transcription, activation of the precursor zymogens and inhibition by endogenous inhibitors [26]. Due to their activity, MMPs participate in many physiological and pathological processes in the body such as development, involution, inflammation, tumor growth, and repair $[27,28]$.

Matrix metalloproteinases play an important role in the turnover of almost all extracellular matrix molecules and thus, participate in the pathogenesis of COPD [22,29]. An $A>G$ substitution in the promoter of the MMP7 gene has been shown to affect the promoter activity, as the $G$ allele determines higher basal transcriptional activity in vitro in human monocyte/macrophage cell line U937 [15]. In this study, we did not find any significant difference in geno-type and allele distribution when we studied the entire COPD patient and control groups. However, the carries of the $\mathrm{G}$ allele (AG and GG genotypes) appeared to develop COPD significantly early compared to those with the AA genotype. Moreover, the $\mathrm{G}$ allele determines about a 3-fold higher risk for COPD before the age of 60 years.

So far, only one study has been found in the literature exploring the role of $M M P 7-181 \mathrm{~A}>\mathrm{G}$ (rs11568818) in COPD. In the study of Mogulkoc et al. [23], the MMP-7 AA genotype has been found to be associated with an increased risk of COPD. On the contrary, in our study we found no association of the A allele with COPD, which might be explained by the difference in Bulgarian and

Table 3. Genotype and allele and genotype frequencies of the $M M P 7-181 \mathrm{~A}>\mathrm{G}$ gene polymorphism in the patients with chronic obstructive pulmonary disease and controls younger than 60 years.

\begin{tabular}{|c|c|c|c|c|c|c|c|c|}
\hline \multirow[t]{2}{*}{ MMP7-181A >G } & \multicolumn{2}{|c|}{ Patients } & \multicolumn{2}{|c|}{ Controls } & \multirow[t]{2}{*}{ OR (95\% CI) } & \multirow[t]{2}{*}{$p$ Value } & \multirow[t]{2}{*}{ OR (95\% CI) } & \multirow[t]{2}{*}{$p$ Value } \\
\hline & $n=76$ & Frequency & $n=106$ & Frequency & & & & \\
\hline \multicolumn{9}{|c|}{ Genotype frequency } \\
\hline AA & 11 & 0.145 & 35 & 0.330 & 1.0 (referent) & & 1.0 (referent) & \\
\hline AG & 43 & 0.566 & 50 & 0.471 & $2.736(1.252-5.962)$ & $0.016^{a}$ & 4.742 (1.426-15.768) & $0.011^{a}$ \\
\hline GG & 22 & 0.289 & 21 & 0.198 & 3.333 (1.363-8.148) & $0.008^{\mathrm{a}}$ & $3.194(0.862-11.830)$ & 0.082 \\
\hline $\mathrm{AG}+\mathrm{GG}$ & 65 & 0.855 & 71 & 0.670 & 2.913 (1.380-6.133) & $0.005^{\mathrm{a}}$ & $4.122(1.318-12.890)$ & $0.015^{a}$ \\
\hline \multicolumn{9}{|l|}{ Allele frequency } \\
\hline$-181 \mathrm{~A}$ & 65 & 0.428 & 120 & 0.566 & 1.0 (referent) & - & - & - \\
\hline$-181 \mathrm{G}$ & 87 & 0.572 & 92 & 0.434 & $1.746(1.147-2.657)$ & $0.009^{a}$ & - & - \\
\hline
\end{tabular}

OR: odds ratio; 95\% CI: 95\% confidence interval.

a The bold $p$ values denote that there is a statistical difference. 
Turkish populations (e.g., age, smoking, diagnosis, etc.).

It has been shown that the same variant is not a risk factor for IPF, but influences the plasma level of MMP-7 in patients, as carriers of the AAgenotype had higher concentrations than carriers of other genotypes [21]. MMP7-181A $>\mathrm{G}$ has shown no association with the risk for lung cancer [18]. However, an increased risk for devel-opment of bronchiolitis obliterans syndrome has been reported for carriers of the AA genotype in patients after lung transplantation [20].

In COPD patients, the serum levels of MMP-7, as well as of some other MMPs, MMP-1 and MMP-9, has been found to be significantly higher in exposed to biomass and tobacco smoke when compared with unexposed healthy controls. Moreover, the levels of those enzymes have been found in negative correlation with the lung function indexes (FEV 1 \%pr) [22].

Matrilysin 1 has also been reported to associate with moderate panlobular emphysema as well as with severe and moderate centrilobular emphysema [30]. Matrilysin 1 efficiently cleaves the basement membrane protein entac-tin, which bridges laminin and collagen type IV, and sug-gested a potentially important role for MMP-7 in the dis-ruption of basement membranes by inflammatory cells [31]. Matrilysin 1 is produced by the epithelium of several uninjured, uninflamed tissues, such as lung, liver and breast. Except in intact tissues, matrilysin is expressed in migrating epithelium in injured airways [5].

It has been shown that MMP-7 mediates shedding of E-cadherin from alveolar epithelium during progression of bleomycin-induced pulmonary fibrosis [7]. In specimens of emphysema, strong immunoreactive signal for matrilysin protein has been detected in epithelial cells lining damaged alveoli, especially in cells bordering denuded epithelium [6]. The higher promoter activity of the $\mathrm{G}$ allele may contribute to ongoing epithelial activation by mediating persistent shedding of the E-cadherin ectodomain, altering cell-cell interactions. By cleaving the Fas ligand, matrilysin can regulate apoptosis and it may promote local coagulation by cleaving tissue factor pathway inhibitor [31]. Altogether, these data suggest that the carriers of the $\mathrm{G}$ allele may lead to disruption of ECM and cell-cell interactions, impairment of the process of tissue repair or fibrosis, and thus, to early development of COPD.

In conclusion, the results of our study suggest that MMP7 -181A>G (rs11568818) promoter polymorphism might affect the risk for COPD, as the carriers of the $\mathrm{G}$ allele (AG and GG genotypes) could be considered as predisposing factors for early onset of COPD. This effect could be attributed to the increased production of the enzyme resulting in enhanced airway wall protein degra-dation and injury due to its direct ability for ECM degra-dation. In this respect, the latter suggestion is warranted to be proven by analyzing the possible association of geno-types with serum MMP-7 levels in patients with COPD.

\section{ACKNOWLEDGMENTS}

This study was performed with the support of projects 23/2015 MF and 4/2016 MF, Trakia University, Bulgaria and COST Action CA15129 "Diagnosis, Monitoring and Prevention of Exposure-Related Noncommunicable Diseases (DiMoPEx).”

Declaration of Interest. The authors report no conflicts of interest. The authors alone are responsible for the content and writing of this article.

\section{REFERENCES}

1. GOLD 2017. Global strategy for the diagnosis, management, and prevention of chronic obstructive pulmonary disease 2017 report. [Available from http:// gold copd.org/gold-2017-global-strategy-diagnosismanagement-prevention-copd/.]

2. Echave-Sustaeta JM, Comeche Casanova L, Cosio BG, Soler-Cataluna JJ, Garcia-Lujan R, Ribera X. Comor-bidity in chronic obstructive pulmonary disease. Related to disease severity? Int J Chron Obstruct Pulmon Dis. 2014; 9: 1307-1314.

3. Rabe KF, Hurd S, Anzueto A, Barnes PJ, Buist SA, Calverley P, et al. Global strategy for the diagnosis, management, and prevention of chronic obstructive pul-monary disease: GOLD executive summary. Am J Respir Crit Care Med. 2007; 176(6): 532-555.

4. Hogg JC. Pathophysiology of airflow limitation in chronic obstructive pulmonary disease. Lancet. 2004; 364(9435): 709-721.

5. Parks WC. Matrix metalloproteinases in lung repair. Eur Respir J Suppl. 2003; 44: 36s-8s.

6. Gharib SA, Altemeier WA, Van Winkle LS, Plopper CG, Schlesinger SY, Buell CA, et al. Matrix metallo-proteinase-7 coordinates airway epithelial injury response and differentiation of ciliated cells. Am J Respir Cell Mol Biol. 2013; 48(3): 390-396.

7. McGuire JK, Li Q, Parks WC. Matrilysin (matrix metalloproteinase-7) mediates E-cadherin ectodomain shedding in injured lung epithelium. Am J Pathol. 2003; 162(6): 1831-1843. 
8. Vandenbroucke RE, Dejonckheere E, Libert C. A therapeutic role for matrix metalloproteinase inhibitors in lung diseases? Eur Respir J. 2011; 38(5): 1200-1214.

9. McCawley LJ, Matrisian LM. Matrix metallo-proteinases: They're not just for matrix anymore! Curr Opin Cell Biol. 2001; 13(5): 534-540.

10. Visse R, Nagase H. Matrix metalloproteinases and tissue inhibitors of metalloproteinases: Structure, function, and biochemistry. Circ Res. 2003; 92(8): 827-839.

11. Han JC, Li XD, Du J, Xu F, Wei YJ, Li HB, et al. Elevated matrix metalloproteinase-7 expression promotes metastasis in human lung carcinoma. World J Surg Oncol. 2015; 13(5): 1477-7819.

12. Dunsmore SE, Saarialho-Kere UK, Roby JD, Wilson CL, Matrisian LM, Welgus HG, et al. Matrilysin expression and function in airway epithelium. J Clin Invest. 1998; 102(7): 1321-1331.

13. Li Q, Park PW, Wilson CL, Parks WC. Matrilysin shedding of syndecan-1 regulates chemokine mobilization and transepithelial efflux of neutrophils in acute lung injury. Cell. 2002; 111(5): 635-646.

14. Manicone AM, Huizar I, McGuire JK. Matrilysin (matrix metalloproteinase-7) regulates anti-inflammatory and antifibrotic pulmonary dendritic cells that express CD103 ( $\alpha^{\mathrm{E}} \beta^{7}$-integrin). Am J Pathol. 2009; 175(6): 2319-2331.

15. Jormsjo S, Whatling C, Walter DH, Zeiher AM, Hamsten A, Eriksson P. Allele-specific regulation of matrix metalloproteinase-7 promoter activity is associated with coronary artery luminal dimensions among hyper-cholesterolemic patients. Arterioscler Thromb Vasc Biol. 2001; 21(11): 1834-1839.

16. Beeghly-Fadiel A, Shu XO, Long J, Li C, Cai Q, Cai $\mathrm{H}$, et al. Genetic polymorphisms in the MMP-7 gene and breast cancer survival. Int J Cancer. 2009; 124(1): 208-214.

17. Liu D, Guo H, Li Y, Xu X, Yang K, Bai Y. Association between polymorphisms in the promoter regions of matrix metalloproteinases (MMPs) and risk of cancer metastasis: A meta-analysis. PLoS One. 2012;7(2):14.

18. Scherf DB, Dally H, Muller P, Werle-Schneider G, Jager B, Edler L, et al. Single nucleotide polymorphisms in matrix metalloproteinase genes and lung cancer chemo-therapy response and prognosis. Eur Respir J. 2010; 35(2): 381-390.

19. Ji X, Wang L, Wu B, Han R, Han L, Wang T, et al. Associations of MMP1, MMP2 and MMP3 genes polymorphism with coal workers' pneumoconiosis in Chinese Han Population. Int J Environ Res Public Health. 2015; 12(11): 13901-13912.

20. Kastelijn EA, van Moorsel CH, Ruven HJ, Karthaus V, Kwakkel-van Erp JM, van de Graaf EA, et al. Genetic polymorphisms in MMP7 and reduced serum levels associate with the development of bronchiolitis obliterans syndrome after lung transplantation. J Heart Lung Transplant. 2010; 29(6):680-686.

21. Richards TJ, Park C, Chen Y, Gibson KF, Peter Di Y, Pardo A, et al. Allele-specific transactivation of matrix metalloproteinase 7 by FOXA2 and correlation with plasma levels in idiopathic pulmonary fibrosis. Am J Physiol Lung Cell Mol Physiol. 2012; 302(8): L746-L754.

22. Montano M, Sansores RH, Becerril C, Cisneros J, Gonzalez-Avila G, Sommer B, et al. FEV1 inversely correlates with metalloproteinases 1, 7, 9 and CRP in COPD by biomass smoke exposure. Respir Res. 2014; 15: 74. doi: 1186/1465-9921-15-74.

23. Mogulkoc U, Coskunpinar E, Aynaci E, Caglar E, Ortakoylu MG, Ozkan G, et al. Is MMP-7 gene polymor-phism a possible risk factor for chronic obstructive pul-monary disease in Turkish patients. Genet Test Mol Biomarkers. 2012; 16(6): 519-523.

24. Preacher KJ. Calculation for the $\chi^{2}$ test: An interactive calculation too for $\chi^{2}$ tests of goodness of fit and independence [Computer software]. 2001. [Available from http://www.quantpsy.org/.]

25. Demedts IK, Brusselle GG, Bracke KR, Vermaelen KY, Pauwels RA. Matrix metalloproteinases in asthma and COPD. Curr Opin Pharmacol. 2005; 5(3): 257-263.

26. Lu L, Gunja-Smith Z, Woessner JF, Ursell PC, Nissen T, Galardy RE, et al. Matrix metalloproteinases and collagen ultrastructure in moderate myocardial ischemia and reperfusion in vivo. Am J Physiol Heart Circ Physiol. 2000; 279(2): H601-H609.

27. Yoon HK, Cho HY, Kleeberger SR. Protective role of matrix metalloproteinase-9 in ozone-induced airway inflammation. Environ Health Perspect. 2007; 115(11): 1557-1563.

28. Kofla-Dlubacz A, Matusiewicz M, Krzystek-Korpacka M, Iwanczak B. Correlation of MMP-3 and MMP-9 with Crohn's disease activity in children. Dig Dis Sci. 2012; 57(3): 706-712.

29. Brajer B, Batura-Gabryel H, Nowicka A, KuznarKaminska B, Szczepanik A. Concentration of matrix 
metalloproteinase-9 in serum of patients with chronic obstructive pulmonary disease and a degree of airway obstruction and disease progression. J Physiol Pharmacol. 2008; 59(Suppl 6): 145-152.

30. Ostridge K, Williams N, Kim V, Harden S, Bourne $\mathrm{S}$, Coombs NA, et al. Distinct emphysema subtypes defined by quantitative CT analysis are associated with specific pulmonary matrix metalloproteinases. Respir Res. 2016; 17(1): 92. doi: 1186/s12931-0160402-z.
31. Manjari KS, Jyothy A, Kumar PS, Prabhakar B, Nallari P, Venkateshwari A. Association of matrix metalloproteinase-7 (-181A/G) promoter polymorphism in chronic pancreatitis. Indian J Med Res. 2014; 140(5): 609-615.

32. Belaaouaj AA, Li A, Wun TC, Welgus HG, Shapiro SD. Matrix metalloproteinases cleave tissue factor pathway inhibitor. Effects on coagulation. J Biol Chem. 2000; 275(35): 27123-27128. 